\begin{tabular}{lc}
\hline CURRENT & ISSN: 0973-4929, Vol. 13, №. (2) 2018, Pg. 242-250 \\
WORLD & Current World Environment
\end{tabular}

ENVIRONMENT

Journal Website: www.cwejournal.org

\title{
Determination of Pesticide Residues in Selected Vegetables and Fruits from a Local Market of Lahore, Pakistan
}

\author{
SANA AKHTAR*, GHAZALA YAQUB, ALMAS HAMID, \\ ZAINAB AFZAL and SIDRA ASGHAR
}

Department of Environmental Sciences, Kinnaird College for Women, Lahore.

\begin{abstract}
Increased food products to meet the population needs, has resulted in extensive use of pesticides. However the use of these pesticides is a potential source of contamination of soil and food. The present study was carried out to determine selected pesticides namely bifenthrin, difenoconazole, paraquat, dimethomorph, imidacloprid, deltamethrin residual in fruit (guava) and vegetables (egg plant and round guord) collected from shops in commercial market, Lahore. These samples were prepared and subjected to high pressure liquid Chromatography (HPLC) for detection of pesticide residues. The results showed that in Guava fruit concentration of bifenthrin, difenoconazole, paraquat, diomethomorph and imidacloprid were 5.13, 81.5, 6.6, 0.48 and $1.65 \mathrm{mg} / \mathrm{kg}$ respectively. In Egg Plant sample, bifenthrin, difenoconazole, paraquat, diomethomorph and deltamethrin detected residues were 3.53, $5.62,4.58,0.25$ and $0.005 \mathrm{mg} / \mathrm{kg}$ respectively while imidacloprid residues were not detected. In Round Gourd, the values of bifenthrin, difenoconazole, paraquat, diomethomorph residues were $3.87,61.53,5.01$ and $0.15 \mathrm{mg} / \mathrm{kg}$ respectively. Despite the fact that pesticides are used to control pests and diseases. Yet pesticide residues are left in fruits and vegetables which can pose potential health risks to the consumers. Therefore, need of continuous pesticide residue monitoring is highly recommended.
\end{abstract}

\section{Introduction}

The global demand for food is on the rise to meet the demands of expanding population. It has been estimated that on an average more than $45 \%$ of the world's food crops are destroyed due to insect pests and plant diseases ${ }^{1}$. In order to manage these pesticides have been widely used by the farmers to control the pests and diseases ${ }^{2}$. The history of pest control dates back many centuries where farmers initially used agents such as sulphur and DDT to protect their crops. Soon the detrimental effects of these agents on the consumers surfaced, leading to 
the exploration of other agents such as chlorinated pesticides $^{3}$.

Pakistan being an agro-based country has agriculture as the second highest contributing factor to its GDP. Use of pesticides in Pakistan with a dramatic increase during last 20 years $^{3}$. Although, pesticides plays vital role in maintain high agricultural productivity and are thus considered as the most important component of modern farming. However, for high input intensive agricultural farming the extensive practice of using pesticides has emerged as a prevailing issue of concern. Nevertheless, reliance on pesticides is difficult to sustain due to unintended long term and chronic adverse effects of pesticides on human health and environment ${ }^{4}$. Common pesticides in use for fruits and vegetables includes Organophosphates, Organochlorines, Pyrethroids and Carbamates. Although some organochlorine pesticides are banned in many countries still these pesticides are being used in some developing countries like Pakistan ${ }^{5}$. Lack of law enforcement and adultered pesticides are a major concern as monitoring is negligent and farmer knowledge is rudimentary ${ }^{6}$. Many studies have shown varying levels of pesticides residues in different fruits and vegetables ${ }^{7-8}$.

Moreover exposure to pesticides residues not only presents health risk to farmers, and mainly those who are directly involved in the handling of pesticides through a contact with the pesticides residues on the poor maintenance of the spraying equipment, unsafe handling, storage and disposal practices and lack of personal protective equipment or failure to use it properly. Furthermore, pesticides are present in all agro based ecosystems but the real risk to humans is through exposure to residues in primary and derived agricultural products ${ }^{9}$.

Pesticides have impacts ranging from acute to chronic upon the human population, biodiversity as well as the primary recipients, the crops. Pesticide use has been reported to have contributed to a $70 \%$ increase in the risk of cancer and birth defects. These effects are observably low in people who have adopted organic diets ${ }^{10}$. Moreover biodiversity is adversely affected as pesticides become a part of the food chain and also reduce the beneficial plants used as animal fodder ${ }^{11}$. Fruits and vegetables are under concern as they are consumed raw and also soil quality deteriorates with continuous pesticide use leading to mineral depletion in the soil as well as its yield ${ }^{6}$. Many researchers worked on pesticides residuals in fruits and vegetables ${ }^{12-15}$. Therefore the aim of the present study was to determine six pesticides namely Bifenthrin, Difenoconazole, Paraquat, Dimethomorph, Imidacloprid, Deltamethrin in eggplant, round guord and guava. Collected samples were subjected to HPLC for detection of selected pesticides.

\section{Material and Methods}

\section{Chemicals and Reagents}

Pesticide analysis grade chemicals, Ethyl Acetate, $\mathrm{NaCl}$, Dichloromethane, Sodium Sulfate (RDH/ Fluka) and HPLC grade Methanol (Merck, Germany), $0.45 \mu \mathrm{m}$ Magna nylon filters (Osmonics) ${ }^{16}$.

\section{Area of Study}

The control group sample i.e. fruit and vegetables without pesticides spray were collected from a local farm near Lahore. The samples of experimental group i.e. fruit and vegetables with pesticides spray were collected from the main market of Lahore (Figure 1).

\section{Collection of Samples and Pretreatment}

Two types of samples i.e. fruit sample Guavas and vegetable samples Round gourd and eggplant were collected. Controlled samples of these selected fruit and vegetables were collected for comparative analysis. One kilogram of sample for each fruit (Guavas) and vegetable (Round gourd and eggplant) were taken as control $(1 \mathrm{Kg})$ and experimental groups $(1 \mathrm{Kg})$ from a fruit and vegetable shop in Main market, Hali Road, Lahore. The collected fruit sample Guava and vegetable samples Round gourd and eggplant were chopped finely, air dried and then dried in oven at $105^{\circ} \mathrm{C}$ for the time period of two days. These dried fruit and vegetable samples were then grinded into a fine powder ${ }^{16}$.

\section{Extraction of Fruit \& Vegetable Sample}

Weighted amount $25 \mathrm{~g}$ of collected fruit and vegetable samples were taken in a separate flasks and $100 \mathrm{ml}$ ethyl acetate and $5 \mathrm{~g}$ of $\mathrm{NaCl}$ were added in to it. Flasks were then sealed with parafilm tape and the seal was pricked with a pin at some points so air can move through. The mixture was shaken well 
and kept for 24 hours. Then it was filtered. Rotary evaporator at a speed of $50 \mathrm{rpm}$ was used to extract the solid from the mixture. The lower organic layer and it was collected in a beaker. To extract any remaining residues, $20 \mathrm{ml}$ of dichloromethane and $20 \mathrm{ml}$ of ethyl acetate were added in the aqueous layer. Again organic layer was separated and added in the same beaker in which we prior we collected organic layer ${ }^{16}$.

\section{Clean up}

For cleanup of fruit and vegetables samples $20 \mathrm{~g}$ of sodium sulphate was added in each sample. Filtration of this mixture using Whattman filter paper was done. For solvent evaporation the mixture was kept in rotary evaporator at $40^{\circ} \mathrm{C}$ temperature and for the collection of remaining residues $20 \mathrm{ml}$ of methanol was added ${ }^{17}$.

\section{Standard Preparation}

Each standard was mixed with methanol to give a stock solution of $1 \mu \mathrm{g} / \mathrm{mL}$. For standards preparation, $1 \mathrm{~g}$ of each compound, $30 \mathrm{ml}$ of distilled water and $30 \mathrm{ml}$ of solvents were mixed. Further dilutions for HPLC were done with $5 \mathrm{ml}$ methanol ${ }^{16}$.

\section{Analytical Technique}

For the analysis an Agilent 1260 HPLC system was used. The column used was Zorbax Eclipse Plus C8 Rapid Resolution with diameter of $4.6^{*} 100 \mathrm{~mm}$ and 3.5 micron particle size.

The flow rate was kept at $1.0 \mathrm{ml} / \mathrm{min}$ and injection volume used was $5.0 \mu \mathrm{l}$. Temperature was maintained at $25^{\circ} \mathrm{C}$. The diode array detector (DAD) detected the bandwidth of $208 \mathrm{~nm}$ with reference of bandwidth $360 \mathrm{~nm}$. The mobile phase was water: acetonitrile. The method detection limit was found between $0.001-0005$ while quantification limit was from 0.002 . Internal standards of respective pesticides were used. The process of HPLC took almost 2-3 hours (run time and data processing) to provide results. The results were detected by DAD in the form of graphs showing peaks at different points ${ }^{16}$.

\section{Method Development and Quality Control}

To determine pesticides concentration in selected fruit and vegetables sample, a rapid gradient and sensitive HPLC-UV method was evaluated and validated. Parameters of HPLC such as temperature of column, solvent ratio, wavelength $\mathrm{pH}$, post time, sample and injection volume, and flow rate, etc were optimized for method development.

To achieve authentic and precise results triplicate analysis of each sample was done to point out the variation (if any). Instrument was calibrated for precision, accuracy and linearity. Signal-noise ratio limits were calculated i.e for detection (3:1) and for quantification $(10: 1)^{16}$.

\section{Qualitative Analysis}

To measure the presence of selected pesticides in experimental and control samples qualitative analysis was performed. For qualitative analysis retention factor $(k)$ and response of the peak in the chromatogram of the standard chromatogram were compared with the sample chromatogram.

Presence of pesticides i.e. Bifenthrin, Difenoconazole, Paraquat, Dimethomorph, Imidacloprid, Deltamethrin was noted in all the samples of vegetables and fruit in various ranges by this comparison. In controlled groups of vegetables and fruit no pesticide was observed $^{16}$.

\section{Quantification Analysis}

After qualitative analysis, quantification was done for which concentration of all pesticide in selected vegetables and fruit samples. Identified, peak areas were used for quantification analysis. To achieve the amount of detected byproducts in each sample, quantitative analysis using the formula formulated by chromo academy was used.

Response factor $=($ Peak area of standard $) /($ Standard amount used in $1 \mathrm{ml}$ of solvent)

Amount of standard in sample $=$ (Peak area (sample peak))/(Response factor of selected byproduct)

\section{Results}

Figure 1 represents the selected main market from Lahore. Comparison of retention time of standard chromatogram, with the samples chromatogram retention time was done to assess the presence of pesticides in agriculturally incurred samples. Selected pesticides namely Bifenthrin, Difenoconazole, Paraquat, Dimethomorph, Imidacloprid, Deltamethrin (Table: 1 ) were detected in all samples used in this 
study i.e. Round gourd, Egg plant and Guava (Table: 2) in various concentrations. It was found that in the samples of control group no pesticide was measured. These detected concentrations in all samples of fruits and vegetables were then compared with Maximum Residue Limits (MRLs). Samples were analyzed in triplicate and the concentration of pesticides with maximum residue limits by Codex standards are illustrated in Table 3, 4 and 5.

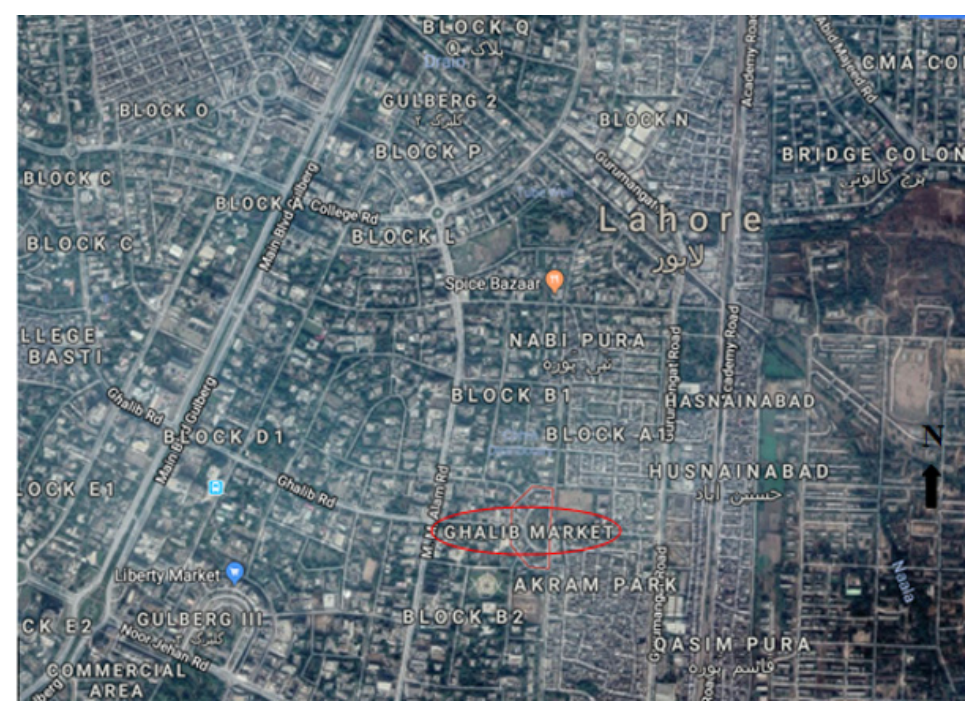

Fig. 1: Google map of selected main market Lahore Pakistan.

Table 1: Pesticide selected for detection in fruit and vegetables samples

\begin{tabular}{|c|c|c|c|}
\hline $\begin{array}{l}\text { Sr. } \\
\text { No. }\end{array}$ & Pesticide Name & Chemical Name & $\begin{array}{l}\text { Molecular } \\
\text { Formula }\end{array}$ \\
\hline 1. & Bifenthrin & $\begin{array}{l}\text { 2-Methyl-3-phenylphenyl)methyl } \\
\text { (1S,3S)-3-[(Z)-2-chloro-3,3,3- } \\
\text { trifluoroprop-1-enyl]- 2,2- } \\
\text { dimethylcyclopropane-1- } \\
\text { carboxylate }\end{array}$ & $\mathrm{C}_{23} \mathrm{H}_{22} \mathrm{ClF}_{3} \mathrm{O}_{2}$ \\
\hline 2. & Difenoconazole & $\begin{array}{l}\text { 1-[2-[2-chloro-4-(4- } \\
\text { chlorophenoxy)phenyl] -4- } \\
\text { methyl-1,3-dioxloan-2-ylmethyl]- } \\
\text { 1H-1,2,4-triazole }\end{array}$ & $\mathrm{C}_{19} \mathrm{H}_{17} \mathrm{Cl}_{2} \mathrm{~N}_{3} \mathrm{O}_{3}$ \\
\hline 3. & Paraquat & $\begin{array}{l}\text { (1,10 -dimethyl- } 4,40 \\
\text {-bipyridinium dichloride) }\end{array}$ & $\mathrm{C}_{12} \mathrm{H}_{14} \mathrm{Cl}_{2} \mathrm{~N}_{2}$ \\
\hline 4. & Dimethomorph & $\begin{array}{l}\text { 4-[3-(4 chlorophenyl)-3-(3,4- } \\
\text { dimethoxyphenyl)-1-oxo-2- } \\
\text { propenyl] morpholine }\end{array}$ & $\mathrm{C}_{22} \mathrm{H}_{22} \mathrm{CINO}_{4}$ \\
\hline 5. & Imidacloprid & $\begin{array}{l}\text { 1-(6-chloro-3- pyridylmethyl)-N- } \\
\text { nitroimidazolidin-2-ylideneamine }\end{array}$ & $\mathrm{C}_{9} \mathrm{H}_{10} \mathrm{CIN}_{5} \mathrm{O}_{2}$ \\
\hline 6. & Deltamethrin & $\begin{array}{l}\text { [(S)-Cyano-(3-phenoxyphenyl)- } \\
\text { methyl] (1R,3R)-3-(2,2- } \\
\text { dibromoethenyl)-2,2-dimethyl- } \\
\text { cyclopropane-1-carboxylate }\end{array}$ & $\mathrm{C}_{22} \mathrm{H}_{19} \mathrm{Br}_{2} \mathrm{NO}_{3}$ \\
\hline
\end{tabular}


Table 2: Fruit and vegetable samples Used for Study

\begin{tabular}{cllll}
\hline Sr. No. & Sample Type & Sample Name & Botanical Name & Sampling Site \\
\hline 1. & Vegetables & Round gourd & Lagenaria siceraria & $\begin{array}{l}\text { local farm near } \\
\text { Lahore } \\
\text { main vegetable } \\
\text { market of Lahore }\end{array}$ \\
& Egg plant & Solanum melongena & $\begin{array}{l}\text { local farm near } \\
\text { Lahore } \\
\text { main vegetable } \\
\end{array}$ \\
& Fruit & Guavas & Psidium guajava & $\begin{array}{l}\text { local farm near } \\
\text { lahore }\end{array}$ \\
& & & $\begin{array}{l}\text { Lain vegetable } \\
\text { market of Lahore }\end{array}$ \\
& & &
\end{tabular}

Table 3: Comparison of detected pesticide concentration in Guava with Codex Standard

\begin{tabular}{|c|c|c|c|}
\hline $\begin{array}{l}\text { Sr. } \\
\text { No. }\end{array}$ & Pesticides & $\begin{array}{c}\text { Detected } \\
\text { Concentrations } \\
(\mathrm{mg} / \mathrm{kg})\end{array}$ & MRLs (mg/kg) \\
\hline 1. & Bifenthrin & 5.13 & 0.03 \\
\hline 2. & Difenoconazole & 81.5 & $N A^{*}$ \\
\hline 3. & Paraquat & 6.6 & 0.01 \\
\hline 4. & Diomethomorph & 0.48 & NA \\
\hline 5. & Imidacloprid & 1.65 & 1.0 \\
\hline 6. & Deltamethrin & $N D^{* *}$ & NA \\
\hline \multicolumn{4}{|c|}{$\begin{array}{l}{ }^{*} \mathrm{NA}=\text { Not Available } \\
{ }^{*} \mathrm{ND}=\text { Not Detected }\end{array}$} \\
\hline \multicolumn{4}{|c|}{$\begin{array}{c}\text { Table 4: Comparison of detected pesticide concentration in } \\
\text { Egg Plant with Codex Standard }\end{array}$} \\
\hline $\begin{array}{l}\text { Sr. } \\
\text { No. }\end{array}$ & Pesticides & $\begin{array}{c}\text { Detected } \\
\text { Concentrations } \\
(\mathrm{mg} / \mathrm{kg})\end{array}$ & MRLs (mg/kg) \\
\hline 1. & Bifenthrin & 3.53 & 0.2 \\
\hline 2. & Difenoconazole & 5.62 & 1.0 \\
\hline 3. & Paraquat & 4.58 & 0.05 \\
\hline 4. & Diomethomorph & 0.25 & 1.0 \\
\hline 5. & Imidacloprid & $N D^{\star *}$ & $N A^{*}$ \\
\hline 6. & Deltamethrin & 0.005 & $N A^{*}$ \\
\hline
\end{tabular}

${ }^{*} \mathrm{NA}=$ Not Available

${ }^{* *} \mathrm{ND}=$ Not Detected 
Table 5: Comparison of detected pesticide concentration in Round Gourd with Codex Standard

\begin{tabular}{cccc}
\hline Sr. & Pesticides & $\begin{array}{c}\text { Detected } \\
\text { Concentrations } \\
(\mathbf{m g} / \mathbf{k g})\end{array}$ & MRLs $\mathbf{( m g / k g )}$ \\
\hline No. & Bifenthrin & 3.87 & 2.0 \\
2. & Difenoconazole & 61.53 & 0.5 \\
3. & Paraquat & 5.01 & 0.02 \\
4. & Diomethomorph & 0.15 & 0.5 \\
5. & Imidacloprid & $\mathrm{ND}^{* *}$ & $\mathrm{NA}^{*}$ \\
6. & Deltamethrin & $\mathrm{ND}^{* \star}$ & $\mathrm{NA}^{*}$ \\
\hline
\end{tabular}

${ }^{*} \mathrm{NA}=$ Not Available

${ }^{* \star} \mathrm{ND}=$ Not Detected

\section{Discussion}

Different varieties of pesticides are used in order to avoid the pest infestation in food crops but if maximum permissible limit for the intake of pesticide increases then it could result in different kinds of disease ${ }^{18}$. Results of many investigated pesticides indicated that toxins are absorbed and carried into the different organs of the body, where the metabolizing enzymes are responsible for both its bio-activation and detoxification into different body tissues ${ }^{19}$.

According to analyzed fruit \& vegetables, Guava was found to be contaminated with bifenthrin (5.13 $\mathrm{mg} / \mathrm{kg})(\mathrm{MRL}=0.03 \mathrm{mg} / \mathrm{Kg})$, Egg plant $(3.53 \mathrm{mg} / \mathrm{kg})$ (MRL $=0.2 \mathrm{mg} / \mathrm{Kg}$ ) but in Round gourd no bifenthrin residues were found. Bifenthrin concentration in all samples observed to exceeding MRLs. Bifenthrin because of its highly toxic nature known as restricted use pesticide. Bifenthrin was sprayed on fruits, cotton and vegetables to combat insects and pests. Bifentrin pesticide inhibited ATPase enzyme production and nervous system damage causing paralysis and at the end death of the insects. It is carcinogenic for humans when ingested. Bifenthrin disrupts the nervous system and causes paralysis in insects ${ }^{20}$. Bifenthrin has potential to pollute water sources and having high soil affinity and also adsorb in sediments. Another study conducted on pesticide residues in different Fruit samples collected from various fruit markets of Lahore city, Punjab also detected bifenthrin concentration in Guava fruit $(0.06 \mathrm{mg} / \mathrm{kg})^{16}$. Difenoconazole is also widely used insecticide for crop protection. Difenoconazole was found in the concentration of $81.5 \mathrm{mg} / \mathrm{kg}$ $(\mathrm{MRL}=\mathrm{NA}), 5.62 \mathrm{mg} / \mathrm{kg}(\mathrm{MRL}=1.0 \mathrm{mg} / \mathrm{Kg})$ and 61.53 $\mathrm{mg} / \mathrm{kg}(\mathrm{MRL}=0.5 \mathrm{mg} / \mathrm{Kg})$ in Guava, Egg plant and Round gourd respectively. Detected concentrations of difenoconazole in all samples were above Codex Standards and also concentration of difenoconazole was higher than bifenthrin concentration in vegetables and fruits samples. Reason behind this high concentration of difenoconazole in selected samples was improper irrigation practices that cause humidity and results fungal diseases in vegetable samples. It was also reported that by peeling fruits and vegetables insecticides and pesticides residual concentrations can be decreased because these toxic elements more soaked in the surface of fruits and vegetables than inner fruit body ${ }^{18}$. Moreover, Difenoconazole intake can cause depression, weight gain, hot flushes, intense sweetening and early onset of menopause. Other effects include bone weakness, risks of blood clotting and gastro intestinal disturbance as suggested by ${ }^{21}$.

Paraquat pesticide is used to control weeds and applied for pre-plant or as pre emergent for vegetables and post emergent for fruits. Paraquat is also a restricted product and in some countries this pollutant was banned. Levels of paraquat detected in the samples were also exceeding MRLs with $6.6 \mathrm{mg} / \mathrm{kg}(\mathrm{MRL}=0.01 \mathrm{mg} / \mathrm{Kg})$ in guava, 4.58 $\mathrm{mg} / \mathrm{kg}(\mathrm{MRL}=0.05 \mathrm{mg} / \mathrm{Kg})$ in Egg plant and $5.01 \mathrm{mg} / \mathrm{kg}$ (MRL $=0.02 \mathrm{mg} / \mathrm{Kg}$ ) in Round gourd. The reason behind increased levels of paraquat pesticides was that farmers apply it without observing proper time period gaps after the harvesting of crops. 
Farmers because of their negligence sprayed it in higher amount than required and this action leaves residues in crops that become the cause of vegetables and fruit contamination ${ }^{22}$. Moreover, its chronic exposure can cause adverse effects on the respiratory system, e.g. reduced lung function. Paraquat intake is also associated with increased incidence of leukaemia, lymphoma, skin and brain cancer in the individuals as suggested by Wesseling et al., ${ }^{23}$.

Diomenthomrph is slightly toxic compound and used as a fungicidal spray. It prevents vegetables and fruits from molds by killing them and controlling their spread. Guava, Egg plant and Round gourd exhibited diomenthomrph concentrations $0.48 \mathrm{mg} / \mathrm{kg}(\mathrm{MRL}=\mathrm{NA}), 0.25 \mathrm{mg} / \mathrm{kg}(\mathrm{MRL}=1.0$ $\mathrm{mg} / \mathrm{Kg})$, and $0.15 \mathrm{mg} / \mathrm{kg}(\mathrm{MRL}=0.5 \mathrm{mg} / \mathrm{Kg})$ respectively. In Guava, Egg plant diomenthomrph was within permissible residue limits while in Round gourd it exceeded from MRL value.

Imidacloprid pesticide is very soluble and mobile therefore it leaches into ground water sources. This pesticide is commonly applied to cereals, potatoes, fruits, vegetables, cotton, rice and maize to control pests, termites and many other sucking insects. Residues of imidacloprid were only found in Guava. Concentration of imidacloprid detected in Guava was $1.65 \mathrm{mg} / \mathrm{kg}$ (MRL $=0.5 \mathrm{mg} / \mathrm{Kg})$ which exceeded MRLs. In vegetable samples Round gourd and Egg plant imidacloprid was not detected.

Deltamethrin is a synthetic pyrethroid insecticide. Deltamethrin was not found in round gourd and guava, while egg plant was found to be contaminated at a lowest concentration of $0.005 \mathrm{mg} / \mathrm{kg}$. Pesticides residual in vegetables and fruits become a concerning issue now a days. Moreover, the occurrence of multi-residue pesticide contamination in different commodities has also been reported in other investigations ${ }^{24-25}$. Pesticides should be used in safe limits as given by different regulatory bodies to avoid adverse effects of these pesticides on humans.

From the results of detected concentrations of Bifenthrin, Difenoconazole, Paraquat, Dimethomorph, Imidacloprid, Deltamethrin in Guava, Egg plant and Round gourd samples, the trends of selected pesticides in all these samples were as follows:
Bifenthrin = Guava $>$ Round gourd $>$ Egg plant Difenoconazole $=$ Guava $>$ Round gourd $>$ Egg plant

Paraquat $=$ Guava $>$ Round gourd $>$ Egg plant

Concentration of bifenthrin, difenoconazole and paraquat were in the same order in Guava Round gourd and Eggplant samples but varies in their range. While the concentrations of dimethomorph, imidacloprid and deltamethrin only exceeded in Round gourd, Guava and Egg plant samples respectively as discussed earlier. Furthermore these pesticide residues were also reported but in different varieties of fruits and vegetables ${ }^{26-30}$.

Pesticides absorbed in fruits and vegetables and become a part of the food chain. However, application of these poisonous elements is hazardous for environment and humans too, when they ingested that contaminated food. Pesticides accumulates in the body tissues as they are not easily soluble ${ }^{31-32}$. Integrated pest management (IPM) is the basic way to avoid pesticide spray. It includes measurement of threshold of pests in the field and identification of pests that whether they are destructive or not. It is recommended that in case of great necessity, targeted spraying is recommended instead of broadcast spraying.

\section{Conclusion}

From this research study it was concluded that the vegetables and fruit samples that were grown without any pesticide spray on them i.e. control group did not show any pesticide residues in them. The samples of vegetables and fruits which were collected from the main vegetable market Lahore showed the presence of pesticide residues. The detected concentrations of pesticides were exceeding the MRLs and results revealed that concentration of pesticides residual in selected vegetables were above the permissible limits. Therefore, regular checking of vegetables collected from different markets should be done to analyze the concentration of different pesticides in food crops.

\section{Acknowledgements}

Authors would like to thank Kinnaird College for Women, Lahore for providing complete research facilities. 


\section{References}

1. Kolani L, Mawussi G, Sanda K. Assessment of organochlorine pesticide residues in vegetable samples from some agricultural areas in Togo. American Journal of Analytical Chemistry.2016;7(04):332.

2. Mahugija JA, Khamis FA, Lugwisha EH, Determination of Levels of Organochlorine, Organophosphorus, and Pyrethroid Pesticide Residues in Vegetables from Markets in Dar es Salaam by GC-MS. International Journal of Analytical Chemistry. 2017:9.

3. Rasheed MB. Country report on international code of conduct on the distribution and use of pesticide, Department of plant protection, Ministry of Food. Agriculture Livestock, Government of Pakistan. (2007) http:// plantprotection.gov.pk/category/progressreports/

4. Jallow MF, Awadh DG, Albaho MS, Devi VY, Ahmad N, Monitoring of Pesticide Residues in Commonly Used Fruits and Vegetables in Kuwait. International Journal of Environmental Research and Public Health.2017;14(8):833.

5. Montory M, Ferrer J, Rivera D, Villouta MV,Grimalt JO. First report on organochlorine pesticides in water in a highly productive agro-industrial basin of the Central Valley, Chile. Chemosphere.2017;174: 148-156.

6. Hussain Z, Siddique S. Determination of Pesticides in Fruits and Vegetables using Acetonitrile Extraction and GC/MS Technique. Journal of Scientific Research.2010; 2:19-29.

7. Parveen Z, Riazuddin Iqbal S, Khurro $M$, Bhutto $M$, Ahmed M. Monitoring of multiple pesticide residues in some fruits in Karachi, Pakistan. Pakistan Journal of Botany.2011;43(4):1915-1918.

8. Mebdoua S, Lazali M, Ounane SM, Tellah S, Nabi F, Ounane G. Evaluation of pesticide residues in fruits and vegetables from Algeria. Food Addit Contam: Part B.2017;10(2):9198.
9. Jallow MF, Awadh DG, Albaho MS, Devi VY, Thomas BM. Pesticide knowledge and safety practices among farm workers in Kuwait: results of a survey. International Journal of Environmental Research and Public Health.2017;14(4):340.

10. Khooharo A, Memon R, Mallah M. An empirical analysis of pesticide marketing in Pakistan. The Pakistan Development Review.2008;46(1):57-74.

11. Khan AM, Iqbal M, Ahmad I, Soomro,H. M. Economic evaluation of pesticide use externalities in the cotton zones of Punjab, Pakistan. The Pakistan Development Review.2002;41(4):683-698.

12. Ramesh H.L, Murthy VNY. Evaluation of Pesticide Residual Toxicity in Vegetables and Fruits Grown in Bangalore Rural District. International Journal of Pharmaceutical Sciences Review and Research.2013; 21(2): 52-57.

13. Islam MA, Islam MZ, Hossain MK, Residual analysis of selected pesticides in cucumber and spinach collected from local markets of Mymensingh sadar. Progressive Agriculture,2015;26:38-44.

14. Munawar A, Hameed SW, Sarwar M, Identification of pesticide residues in different vegetables Collected from market of Lahore, Pakistan. Journal of Agroalimentary Processes and Technologies.2013;19(4): 392-398.

15. Dasika R, Tangirala S, Naishadham P, Pesticide residue analysis of fruits and vegetables. Journal of Environmental Chemistry and Ecotoxicology.2012;4(2): 19-28.

16. Shafi $M$, Imran $M$, Sarwar $M$, Kalsoom S, Mujahid H. A Study of Pesticide Residues in Different Fruits Collected from Different Fruit Markets of Lahore, Punjab. Journal of Agroalimentary Processes and Technologies,.2014;20(4):298-303.

17. Sharpe RM, Irvine DS. How strong is the evidence of a link between environmental chemicals and adverse effects on human 
reproductive health. British Medical Journal.2004;328(7437):447.

18. Khan SM, Shah MM, Mahmood Q, Hassan A, Akbar K Assessment of pesticide residues on selected vegetables of Pakistan. Journal of Chemical Society of Pakistan.2011;33(6): 816-821.

19. Poet T.S, Wu H, Kousba AA, Timchalk C., In vitro rat hepatic and intestinal of the organophosphate pesticides chlorpyrifos and diazinon. Toxicological Sciences.2003;72: 193-200.

20. Cox C. Surgan M. Unidentified inert ingredients in pesticides: implications for human and environmental health. Environmental Health Perspectives.2006; 114(12):1803.

21. Mu X, Pang S, Sun X, Gao J, Chen J, Chen X, Wang C. Evaluation of acute and developmental effects of difenoconazole via multiple stage zebrafish assays. Environmental Pollution.2013;175:147-15.

22. Akinloye AO, Adamson I, Ademuyiwa O, Arowolo AT. Occurrence of paraquat residues in some Nigerian crops, vegetables and fruits. Journal of Environmental Chemistry and Ecotoxicology.2011;3(7): 195-198.

23. Wesseling C, Aragón A, Castillo L, Corriols,M., Chaverri F, Cruz EDL, De Joode BVW. Hazardous pesticides in central America. International Journal of Occupational Medicine and Environmental Health.2001;7(4):287294.

24. Allen G, Halsall CJ, Ukpebor J, Paul N.D, Ridall G, Jason J, Wargent JJ. Increased occurrence of pesticide residues on crops grown in protected environments compared to crops grown in open field conditions. Chemosphere.2015;119: 1428-1435.

25. Osman KA, Al-Humaid Al, Al-Rehiayani,S. M.,
\& Al-Redhaiman KN. Estimated daily intake of pesticide residues exposure by vegetables grown in greenhouses in $\mathrm{Al}$-Qassim region, Saudi Arabia. Food Control. 2011;22(6): 94-953.

26. Tahir S, Anwar T, Ahmad I, Aziz S, Mohammad A, Ahad K. Determination of pesticide residues in fruits and vegetables in Islamabad market. Journal of Environment Biology.2001;22(1):71-74.

27. Parveen Z, Khuro MI, Kausar N. Evaluation of multiple pesticide residues in apples and citrus fruits, 1999-2001. Pakistan. Bulletin of Contamination and Toxicology.2004;73:312318.

28. Parveen Z, Khuhro MI, Rafiq N. Monitoring of pesticide residues in vegetables (20002003) in Karachi, Pakistan. Bulletin of Contamination and Toxicology.2005;74: 170-176.

29. Hussain S, Masud T, Ahad K. Determination of pesticides residues in selected varieties of mango. Pakistan Journal of Nutrition.2002;1:41-42.

30. Hassan N, Anwar T, Akhtar S, Tahir S, Ahmad I. Pesticides residues limits in vegetables growing around Karachi city, Pakistan. Journal of Experimental Zoology India.2007;10(1):103-106.

31. Wang N, Shi L, Kong D, Cai D, Cao Y, Liu Y, Yu R. Accumulation levels and characteristics of some pesticides in human adipose tissue samples from Southeast China. Chemosphere.2011;84(7):964-971.

32. Savage EP, Keefe TJ, Mounce LM, Heaton RK, Lewis J. A., Burcar, P. J., Chronic neurological sequelae of acute organophosphate pesticide poisoning. Archives of Environmental \& Occupational Health.1988;43(1):38-45. 